\title{
SHOCK METAMORPHISM IN VOLCANIC ROCK DUE TO THE IMPACT OF THE MIGUIR-CAJAS METEORITE IN 1995 AND ITS IMPORTANCE FOR ECUADOR
}

\author{
Theofilos TOULKERIDIS* \\ Universidad de las Fuerzas Armadas ESPE, Sangolquí, Ecuador, and Universidad de Especialidades Turísticas, \\ Department of Earth Sciences and Construction, Quito, Ecuador, e-mail: ttoulkeridis@espe.edu.ec
}

Richard Caleb ECHEGARAY-AVEIGA

Universidad de las Fuerzas Armadas ESPE, Department of Earth Sciences and Construction, Sangolquí, Ecuador, e-mail: calebechegaray@gmail.com

Karen Paola MARTINEZ-MALDONADO

Universidad Nacional de Loja,Loja, Faculty of Energy, Industries and Non-Renewable Natural Resources, Ecuador, e-mail: karen.p.martinez@unl.edu.ec

Citation: Toulkeridis, T., Echegaray-Aveiga, R.C., \& Martinez-Maldonado, K.P. (2021). SHOCK METAMORPHISM IN VOLCANIC ROCK DUE TO THE IMPACT OF THE MIGUIR-CAJAS METEORITE IN 1995 AND ITS IMPORTANCE FOR ECUADOR. GeoJournal of Tourism and Geosites, 35(2), 315-321. https://doi.org/10.30892/gtg.35208-654

\begin{abstract}
In the past of the earth several asteroids and meteoroids have been impacted, but most of these collisions have been eroded and today there are only sometimes direct and indirect indications, such as massive extinctions of species in the form of fossils, layers with content of extraterrestrial material among others. Based on our recent reconnaissance in the field in 2017, we have been able to identify a new impact of a meteorite on volcanic rock of the Miocene Tarqui Formation in central Ecuador. We were able to reveal and reconstruct the corresponding trajectory as well as its impact day being in 1995. Based on known impacts in South America, this is the very first to have been impacted on rocks, which would lead to a clear shock metamorphism. This discovery of the impact on a rock may soon be a major tourist attraction of the country due to its accessibility and importance for being unique in Ecuador and on the continent.
\end{abstract}

Key words: Meteor impact, shock metamorphism, Cajas National Park, tourism, Ecuador

\section{INTRODUCTION}

A form of mass extinction on our planet is credited to the impact of extraterrestrial objects of enormous sizes on a variety of occasions (Hodych and Dunning, 1992; Claeys, Casier and Margolis, 1992; Benton and Twitchett, 2003; White and Saunders, 2005; Benton, 2015).

Of the asteroid impacts on Earth, the most significant occurred in archaic times, late Permian times, as well as late Cretaceous (Ganapathy, 1980, 1982; Smit, 1990; Schulte et al., 2010; Kaiho et al., 2010; Lowe, 2013). Many myths and legends are associated with the appearance of a space object such as Halley's Comet, or of an object that pierced the atmosphere and subsequently impacted. Since ancient times, the Egyptians have linked the flood cycles of the Nile River with the movements of the stars, understanding it as the movement of the gods. The Babylonians predicted time by ruling the facade of heaven (Lowe, 2013).

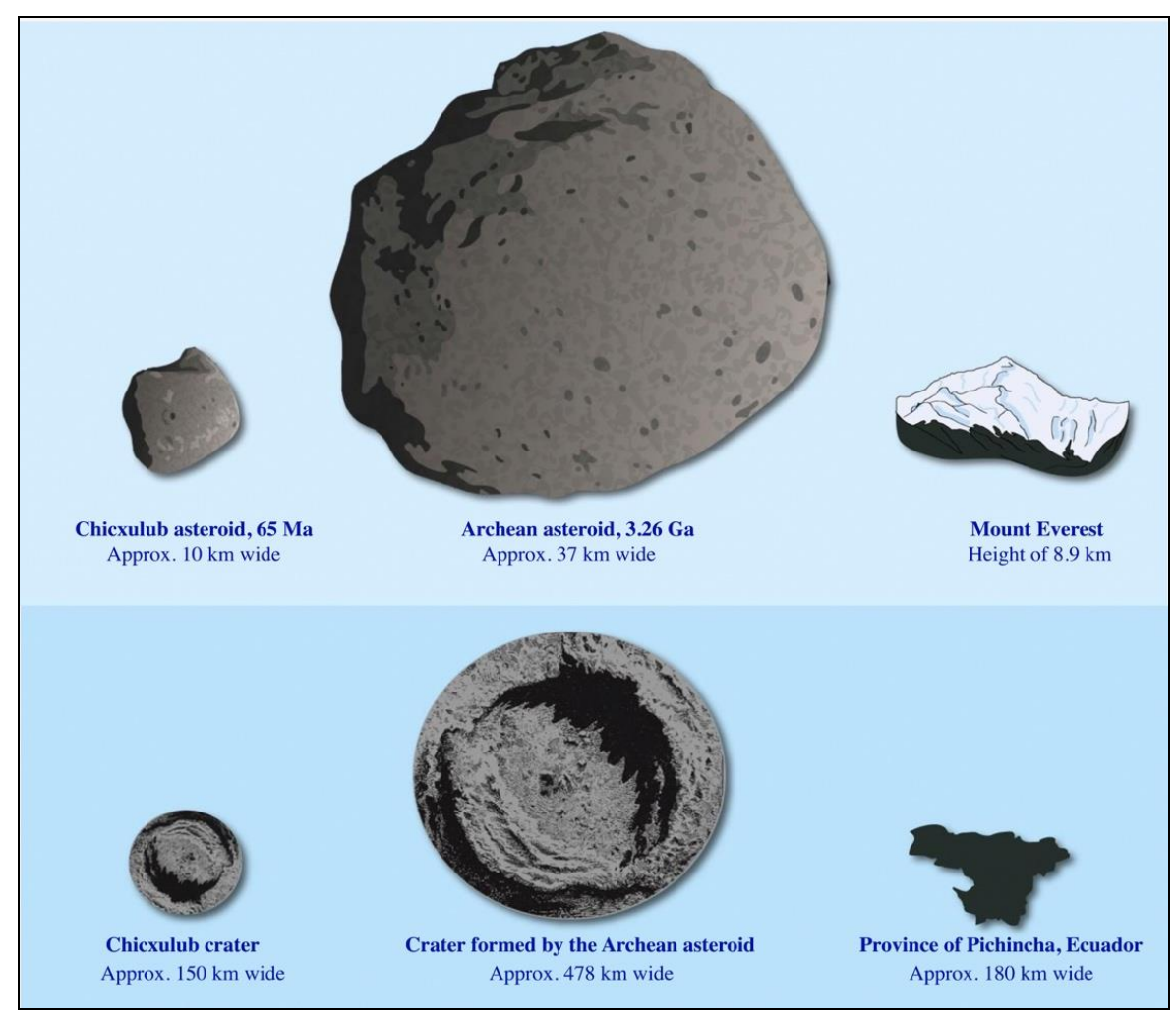

Figure 1. A graphical representation of the sizes of different asteroids and the craters they created. Adapted and modified from American Geophysical Union based on Lowe (2013) 
The Bethlehem star is still considered as the observation of a comet (Humphreys, 1991). However, the appearances of a space object or its impact on Earth are not so exclusive. A considerable amount of materials from space is deposited on the Earth's surface daily. Almost all of these materials arrive unnoticed as dust particles from comets (Humphreys, 1991). There are several pieces of evidence visible today, such as the Barringer Crater near Winslow, Arizona, which is a clear example of what happens when an asteroid hits the Earth's surface (Llorca et al., 2005; DeYoung, 1994; Hager, 1953). It is 1,200 meters in diameter and 200 meters deep and was formed due to the impact of a meteorite around 30 to 50 meters in diameter 50,000 years ago.

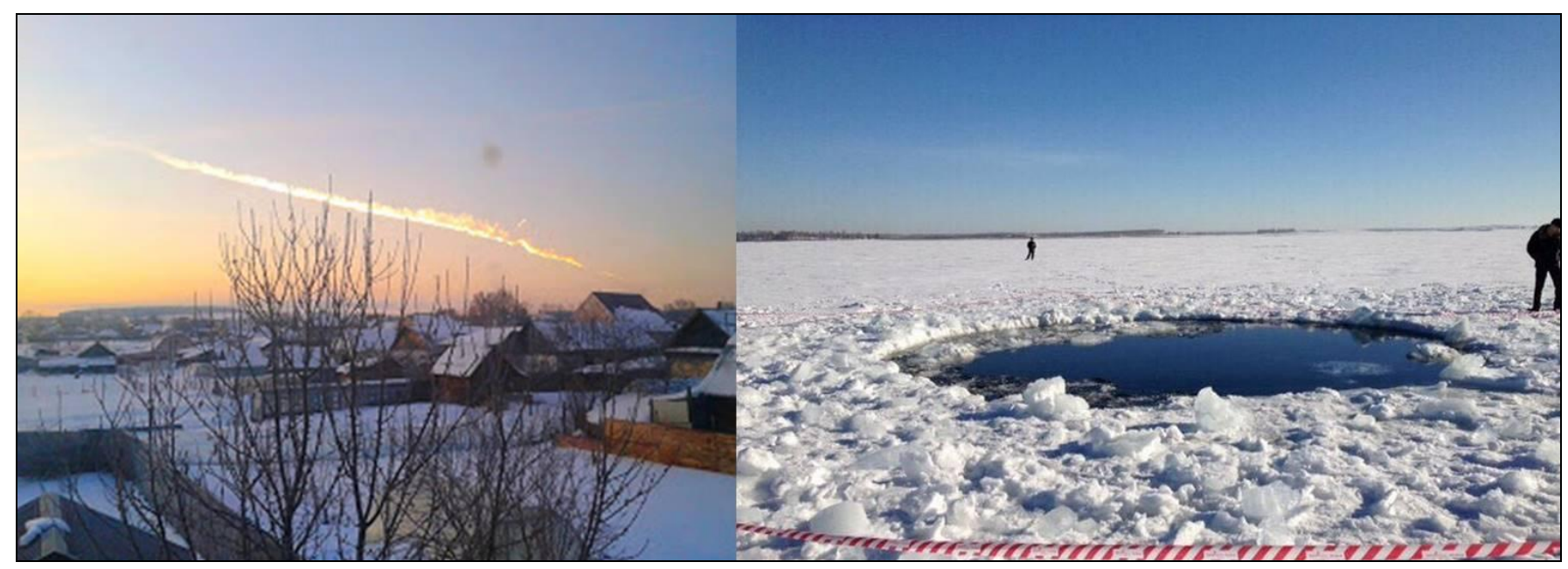

Figure 2. Left: Wake of the fireball over Chelyabinsk; Right: Impact crater on Lake Chebarkul (Extracted from Naukas, 2013)

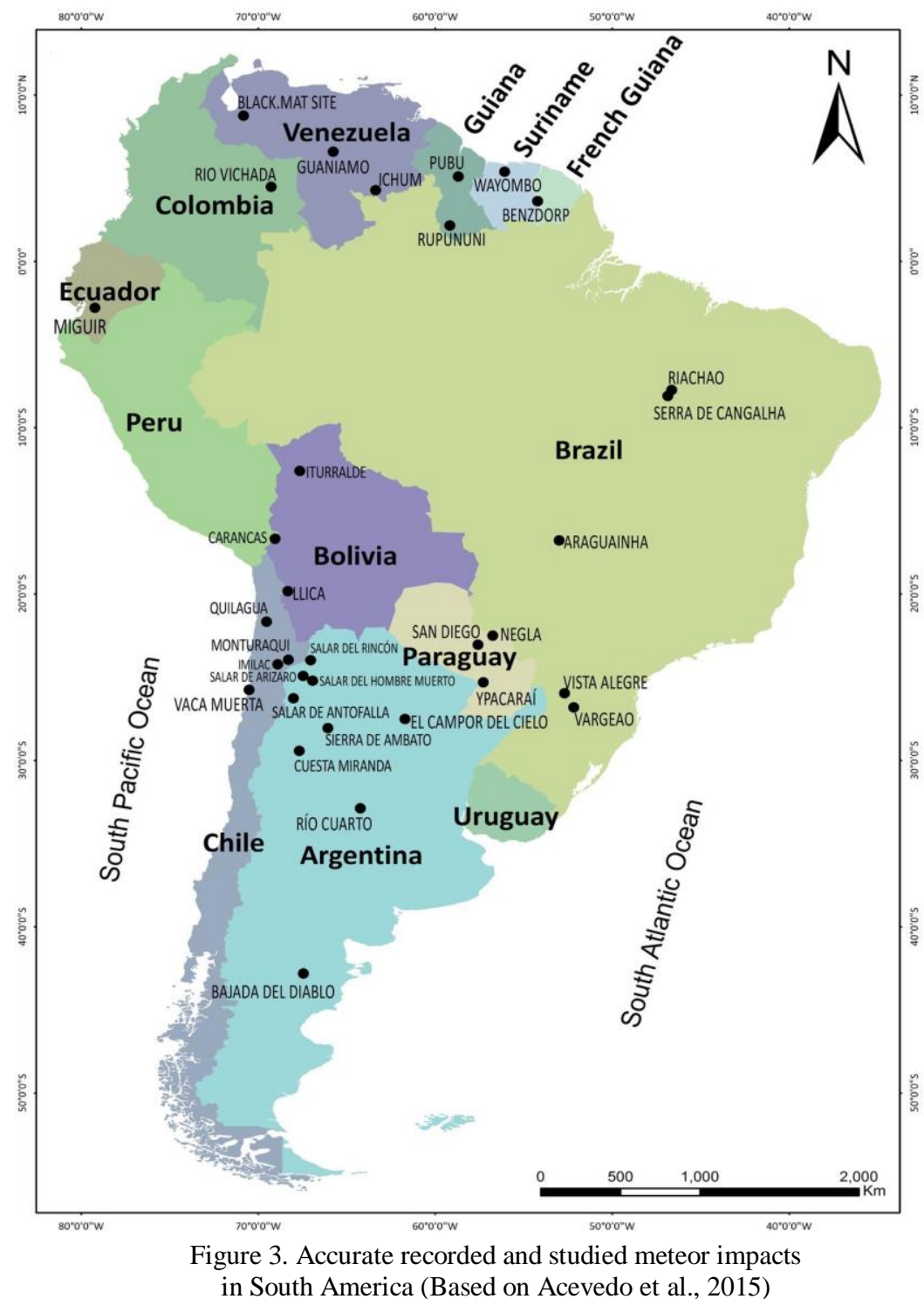

In Tunguska, an uninhabited region of western Siberia, an impact occurred in 1908 as a result of the impact of a 60-meter diameter meteorite, which, unlike the Barringer crater meteorite, completely disintegrated before reaching the ground, which is why no crater was formed (Naukas, 2013; Asher et al., 2005; Napier and Asher, 2009). However, all the trees in an area $50 \mathrm{~km}$ around were burned or felled, generating a noise so loud that it could be heard in London. One of the most recent events of this nature has occurred in the Chelyabinsk region, Russia, where a meteorite fell on February 15, 2013, releasing energy 30 times greater than that of the nuclear bomb dropped on Hiroshima, leaving more than a thousand wounded and material damage worth more than \$ 33.5 million. (Figure 2) (Kolesnikov and Kolesnikova, 2010; Brown et al., 2013; Barry and Kramer, 2013; Popova et al., 2013). Meteorites are extraterrestrial bodies that are not completely disintegrated by the atmosphere and hit the Earth's surface (Acevedo et al., 2015; Svetsov, 1995). They are popularly known as meteorite, meteor, shooting star. Only large, compact meteoroids touch Earth's surface and become meteorites that hit at high speed. Others are micrometeorites that descend with low speed due to friction produced by the air to settle in the ocean or on Earth (Rietmeijer, 2000). Meteorites are traditionally classified by their characteristics into two categories: differentiated and undifferentiated meteorites. The differentiated Meteorites are mainly represented by the achondrites, which are fragments of larger bodies in which there was 
already a differentiation of the chemical elements and represent $8 \%$ of the recorded impacts on Earth. They also include metals (iron) generally made of an iron-nickel alloy, they are very dense and constitute 5\%. Finally, there is the stony-metallic (ironrock) which is $1 \%$ of the meteorites and contains large amounts of rocky and metallic material (Soto, 2004). Undifferentiated Meteorites are chondrites formed by small spheres consisting mainly of silicates and are the most abundant and oldest, representing 86\% of the meteorites recorded on Earth (Moyano-Cambero and Trigo-Rodríguez, 2013).

In South America some 31 craters and impact material have been registered in several countries, of which Argentina stands out with 14 craters (Moyano-Cambero and Trigo-Rodríguez, 2013). Other countries where evidence of extraterrestrial object impacts was found are Brazil, Bolivia, Colombia, Chile, Paraguay, Peru, Uruguay, Venezuela and Las Guayanas (Figure 3) (Acevedo et al., 2015). In Ecuador, there is a record in 1995 of a meteorite fall near the Miguir community in the province of Azuay. Among the main newspapers that recorded information on the event, the HOY newspaper published a report on August 16, 2000 (Diario Hoy, 2000). This impact was registered on Saturday, December 9, 1995, through locals and tourists from the Cajas National Park, as reflected in various YouTube videos, called mainly "The UFO of Cajas". Until now various fragments of the meteorite have been found but never one of the impact sites. This investigation shows the trajectory and the first impact of a meteorite fragment called Miguir-Cajas, in the Province of Azuay, within the Cajas National Park. Another record of a meteorite fall in Ecuador was recorded in Daule on March 23, 2008, leaving no traces so far visible, as the rocks fell into mud and into the river. These are four fragments of up to 20 centimeters in diameter weighing about six kilos, classified as ordinary chondrites. The location of the meteor called "Daule" is Latitude $1^{\circ} 52^{\prime} 15.2$ "S and Longitude 79 ${ }^{\circ} 57^{\prime} 27.2^{\prime \prime} \mathrm{W}$.

\section{ANALYSIS AND RESULTS}

Observations of the surroundings of the impact zone in Azuay

The Cajas National Park is located about $25 \mathrm{~km}$ west of the city of Cuenca, covering about $149 \mathrm{~km} 2$. The morphology is characterized by a variety of elevations, separated from hundreds of lake systems through some 232 lagoons (Figure 4).

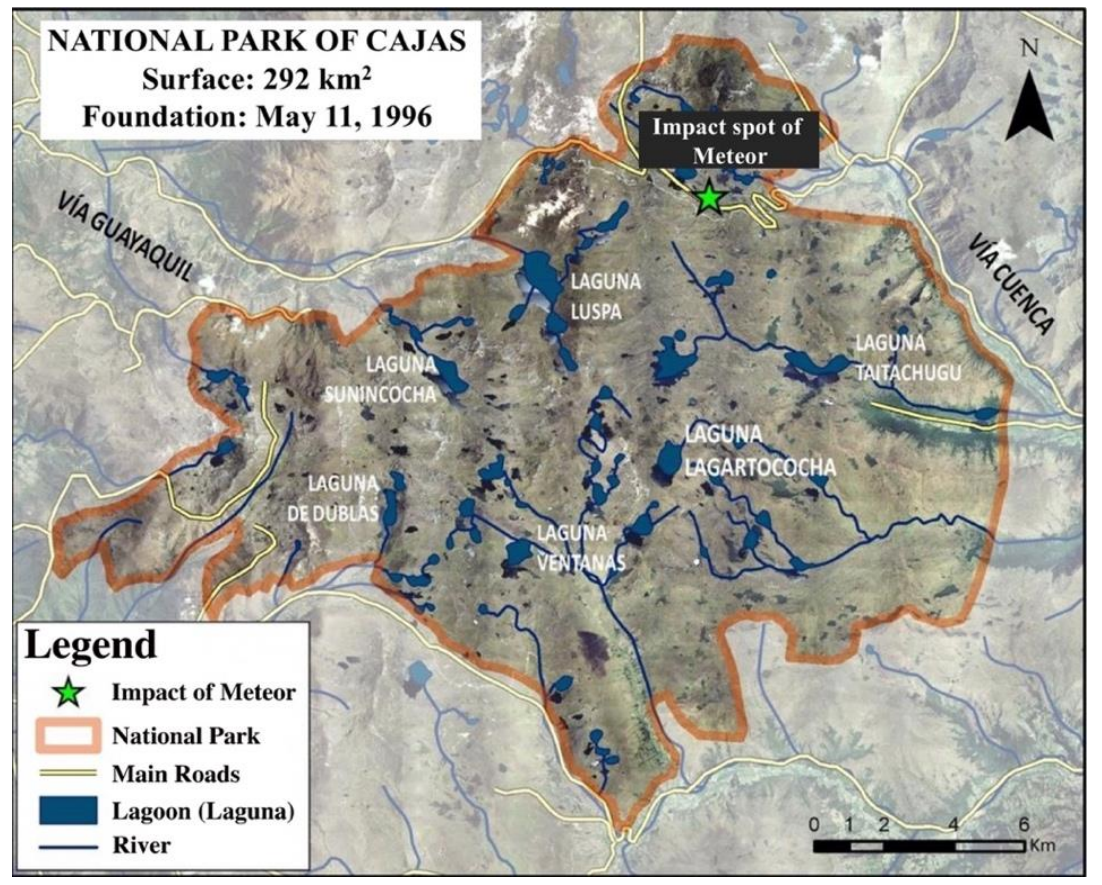

Figure 4. Cajas National Park with impact location
Geomorphology is generally characterized by being of glacial erosion during the Pleistocene, evidencing glacial cirques, Ushaped valleys, ridges, necks, peaks and vertical walls, aberrated rocks and isolated blocks, hanging valleys, glacial deposits such as till, bottom moraines, drumlins, and terminal moraines next to the mentioned glacial lagoons (Acevedo et al., 2011; Goodman, 1996). The geology is characterized by sedimentary and volcanic deposits of basic to intermediate characterization of the Western Cordillera from Paleocenic to Eocenic ages (Navarrete et al., 1999; Pratt et al., 2005; Suhr et al., 2019). On top of these deposits are rocks of the Tarqui Formation, that is, mostly volcanic series from the late Miocene. This formation may be briefly divided into three parts including fine-sized dark andesites, tuff of rhyolitic to dacitic composition, and a layer of a medium-sized homogeneous rhyolite forming visible hills within the park. The tillites are previous till compacted and lithified forming hardened sedimentary

deposits (Navarrete et al., 1999). On March 12, 2017, about 710 meters east northeast of the Interpretation Center, passing the Toreadora Lagoon, in a walk of approximately 12 minutes, we were able to identify a rock metamorphosed by the impact (shock) of the Miguir-Cajas meteor. The impact towards the andesite-type volcanic rock occurred on December 9, 1995, at 2:50 p.m. From the observations and field measurements carried out by us, it has been established that the impact occurred due to a fragment less than one centimeter in size, transforming the volcanic rock into a metamorphic rock, leaving a small crater and radial fissures around the impact. The path of the spatial fragment was determined to be north to south in the direction $5^{\circ} \mathrm{N}$ to $185^{\circ} \mathrm{S}$ with an angle around $25^{\circ}$ (Figures 4-7).

\section{The Importance of the impact of a meteor to Ecuador}

Ecuador situated in a particular geographic and geodynamic environment with the interaction of various tectonic plates is subject of constant movements and associated hazards. Therefore this Andean country together with its Galapagos Islands, situated some $1000 \mathrm{~km}$ west of its mainland, is the focus of far and regional tsunamis, strong earthquakes, extremely frequent mass movements and continuous volcanic activity (Aviles-Campoverde et al., 2021; Hungerbühler et al., 2002; Padrón et al., 2012; Rodriguez et al., 2017; Toulkeridis and Zach, 2017). Such geological events have destroyed a variety of villages and strategic infrastructure, leaving behind huge amounts of victims and enormous economic losses. 
These economic struggles have compromised occasionally the government's GDP leading to social unrest and manifestations (Toulkeridis et al., 2019; Hochstetler, 2006; Lucero, 2001; Korovkin, 2000; Kennemore and Weeks, 2011).

On the other hand, hazards based on atmospheric and or hydro-meteorological phenomena and or processes also have left behind enormous economic losses and occasionally deaths. Such catastrophic events are based on seasonal activities such as rainy or dry seasons as well as the "El Niño" and "La Niña" phenomenona (Perreaulta and Valdivia, 2010; Toulkeridis et al., 2020; Toulkeridis et al., 2016; Mato and Toulkeridis, 2017).

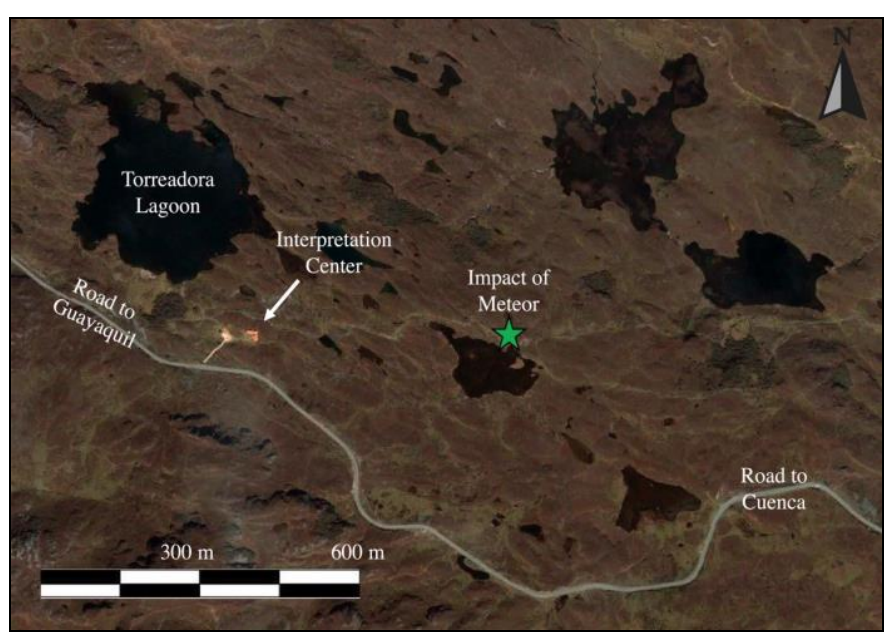

Figure 5. Detailed location of the object's impact zone including the closeness of the Interpretation Center of the Ministry of the Environment. Image extract from Google Earth ${ }^{\mathrm{TM}}$

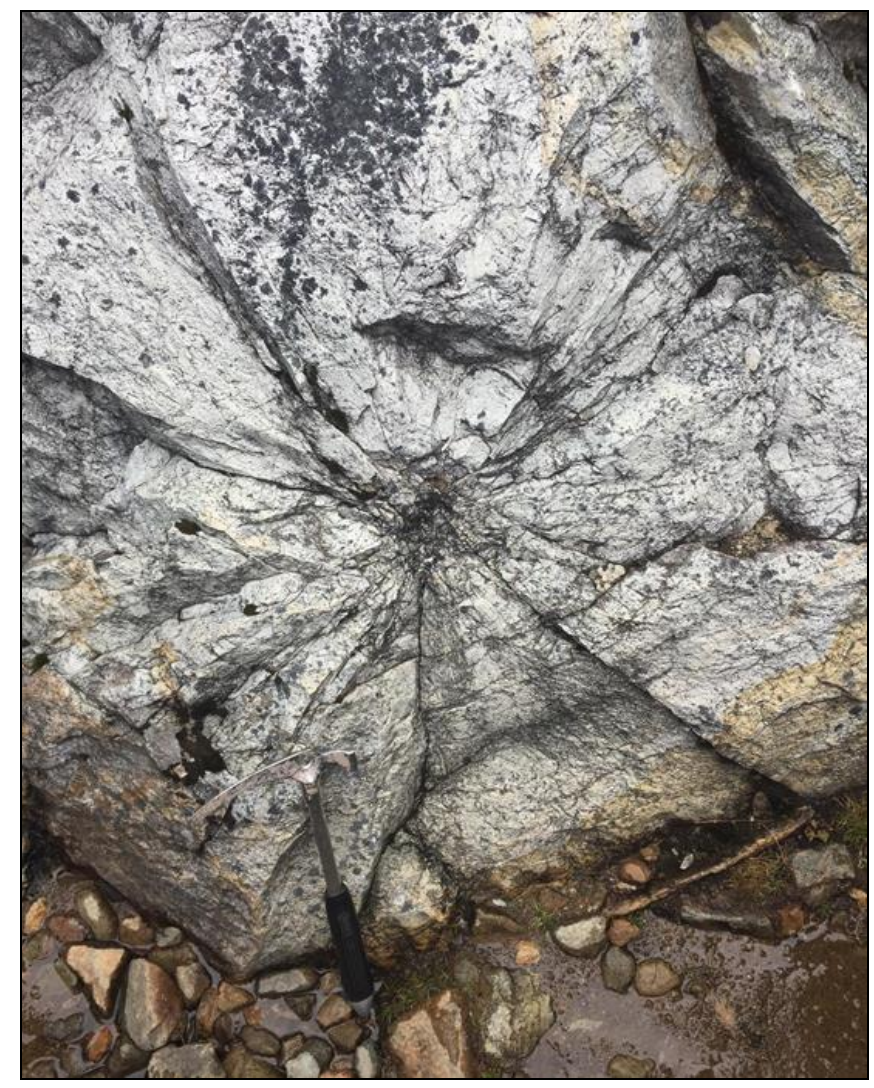

Figure 7. The impact spot in detail within the andesitic

volcanic rock, the exact coordinates of the site are Latitude $2^{\circ}$

$47^{\prime} 00.6$ "S and Longitude $79^{\circ} 12^{\prime} 55.8^{\prime \prime} \mathrm{W}$, as taken by the leading author at its day of discovery on March, 12, 2017

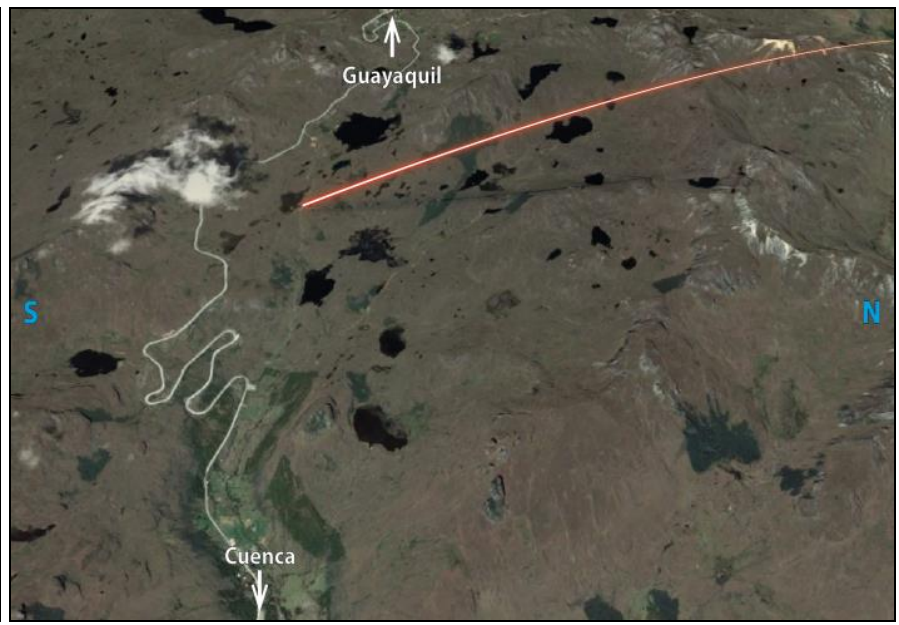

Figure 6. Miguir-Cajas meteor impact trajectory with trajectory from North to South. Image extract from Google Earth ${ }^{\mathrm{TM}}$

Furthermore, due to extreme social and political activities occur extremely often public unrests, which have led to a variety of coups resulting to removals of several presidents, while the dismissal of ministers and deputies is almost of monthly frequency (Edwards, 2015). In the most recent legislation, which shall last for four years, Ecuador has had so far four vice-presidents, due to illegal activities or personal agendas (Lucero, 2001; Korovkin, 2000; Conaghan, 2012). Lastly, corruption and other illicit activities in practically all political social and economic environments paralyze the country and its progress (Marsteintredet, and Uggla, 2019; Lyall, 2018; Buscaglia and Dakolias, 1998).

Despite all aforementioned frequent catastrophic impacts and the continuous political uncertainty, there are still several extraordinary facts about Ecuador to be proud of. Ecuador is known worldwide for its enchanted islands, which belong to the UNESCO Natural Heritage List. Since 1978 there are places in Ecuador that were declared as Natural and Cultural heritage of Humanity through the UNESCO Organization. This list includes the capital of Ecuador with its colonial center, its history and architecture, its historical center being the largest in America. This nomination was followed by Galapagos as a Biosphere Reserve in 1978 and Cuenca, the "Athens of Ecuador", for its buildings and its natural environment in its surroundings in 1999.

Other Ecuadorian icons on this list include the Sangay National Park, the Zárapa language, the traditional weaving of the Ecuadorian toquilla straw hat, also known as Panama Hat, and finally the Qhapaq Nan (Inca Trail, in Quichua), a masterful communication network road, which with its $6,000 \mathrm{~km}$ from south to north covers and crosses Argentina, Chile, Bolivia, Peru, Ecuador and Colombia. Ecuador is also recognized worldwide for its diversity in orchids (4,209 Ecuadorian species of 25 thousand known species), birds (1,640 species of birds in Ecuador of the 9,702 known worldwide), some world-wide scientific discoveries (rose iguana, climbing fish etc.), among its multiculturalism, its archeology (Ingapirca, Cochasquí etc.), caving (Jumandi, Tayos etc.), extreme sports, and now a recognized meteor impact, just a few minutes’ walk in the Cajas National Park (Tobar-Pesántez and Solano-Gallegos, 
2019; Hoese et al., 2015; Martin-Solano et al., 2016; Moliner, 2011; Gentile and Snell, 2009; Ridgely and Greenfield, 2001; Rumazo, 1946; Snow, 1979; Svistoonoff, 1994; Ziólkowski and Sadowski, 1991; Constantin et al., 2019).

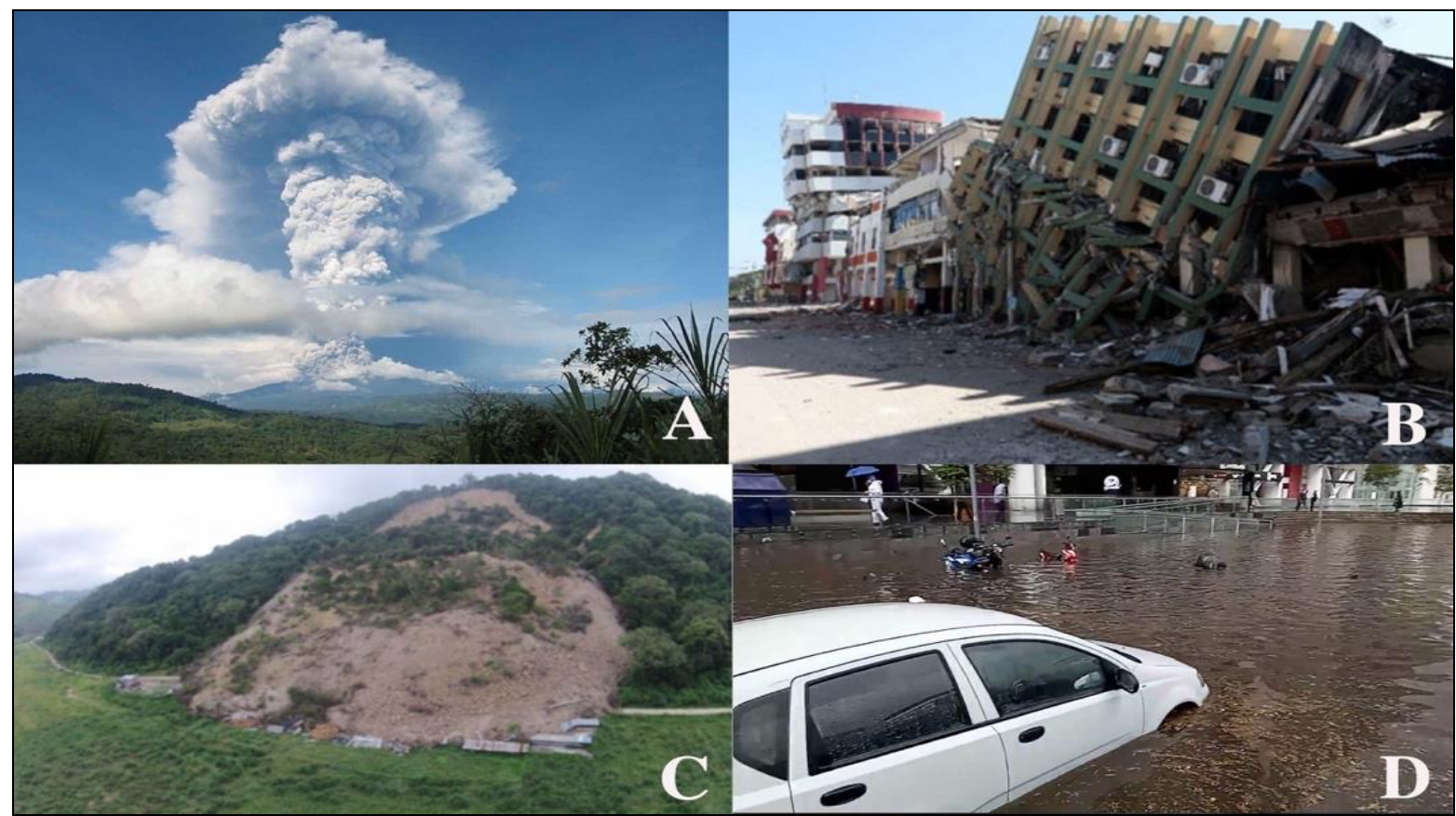

Figure 8. A variety of disasters which have occurred in Ecuador, such as the (a) 3rd of November 2002 eruption of Reventador volcano, (b) the most recent severe 7.8 Mw Earthquake in coastal Ecuador on the 16th of April 2016 and (c) associated mass movement close to Chone, in coastal Ecuadorand (d) flooding after torrential rain in Ecuador's capital Quito on the 7th of July 2020

\section{CONCLUSIONS}

A unique tourist attraction in Ecuador has been found in the Cajas National Park. It is an extraterrestrial impact of the meteor called Miguir-Cajas, which impacted on December 9, 1995 on a volcanic rock.

It was possible to reconstruct the angle of the trajectory as well as the trajectory direction of the space object, as the meteorite has travelled from north to south with a very low angle $\left(25^{\circ}\right)$ prior impact.

The impact has left radial fissures around the impact spot transforming the andesite volcanic rock in almost pure milk quartz appearance due to the shock metamorphism. Due to its special character, as it is the only one recognized so far in the country as well as continent and very accessible to any visitor, it is recommended to protect this rock, while scientific studies of the detail of the rock, the impact, and the space fragments found continue.

\section{Acknowledgement}

We are grateful to the authorities and park-rangers of the Cajas National Park for the permit and logistics to study the impact of the meteorite inside the park.

\section{REFERENCES}

Acevedo, R.D., Rocca, M., Ocampo, A.C., Rabassa, J., Ponce, J.F., \& Stinco, S.G. (2011). Meteorite impact craters and ejecta in South America: a brief review. Revista Brasileira de Geomorfologia, 12(3), 137-160. http://hdl.handle.net/11336/13239

Acevedo, R.D., Rocca, M.C., Ponce, J.F., \& Stinco, S.G. (2015). Impact Craters in South America. Springer briefs in earth system sciences. South America and the Southern Hemisphere, 104 pp.

Asher, D.J., Bailey, M., Emel'Yanenko, V., \& Napier, W. (2005). Earth in the cosmic shooting gallery. The Observatory, 125, 319-322. https://ui.adsabs.harvard.edu/abs/2005Obs...125..319A

Aviles-Campoverde, D., Chunga, K., Ortiz-Hernández, E., Vivas-Espinoza, E., Toulkeridis, T., Morales-Delgado, A. \& Delgado-Toala, D., (2021) Seismically induced soil liquefaction and geological conditions in the city of Jama due to the Mw7.8 Pedernales earthquake in 2016, NW Ecuador. Geosciences, Switzerland, 11(1), 20, 1-22. https://doi.org/10.3390/geosciences11010020

Barry, E., \& Kramer, A.E. (2013). Shock Wave of Fireball Meteor Rattles Siberia, Injuring 1,200. The New York Times, 15. https://www.nytimes.com/2013/02/16/world/europe/meteorite-fragments-are-said-to-rain-down-on-siberia.html

Benton, M.J., \& Twitchett, R.J. (2003). How to kill (almost) all life: the end-Permian extinction event. Trends in Ecology \& Evolution, 18(7), 358-365. https://doi.org/10.1016/S0169-5347(03)00093-4

Benton, M.J. (2015). When Life Nearly Died: The Greatest Mass Extinction of All Time (Revised edition). Thames \& Hudson.

Brown, P.G., Assink, J.D., Astiz, L., Blaauw, R., Boslough, M.B., Borovička, J., Brachet, N., Brown, D., Campbell-Brown, M., Ceranna, L., Cooke, W., de Groot-Hedlin, C., Drob, D.P., Edwards, W., Evers, L.G., Garces, M., Gill, J., Hedlin, M., Kingery, A., Laske, G., Le Pichon, A., Mialle, P., Moser, D.E., Saffer, A., Silber, E., Smets, P., Spalding, R.E., Spurny, P., Tagliaferri, E., Uren, D., Weryk, R.J., Whitaker, R., \& Krzeminski, Z. (2013). A 500-kiloton airburst over Chelyabinsk and an enhanced hazard from small impactors. Nature, 503(7475), 238-241. https://doi.org/10.1038/nature12741

Buscaglia, E., \& Dakolias, M. (1998). An Analysis of the Causes of Corruption in the Judiciary. Law \& Pol'y Int'l Bus., 30 , 95. https://ssrn.com/abstract=931386 
Claeys, P., Casier, J.G., \& Margolis, S.V. (1992). Microtektites and mass extinctions- Evidence for a late Devonian asteroid impact. Science, 257(5073), 1102-1104. https://doi.org/10.1126/science.257.5073.1102

Conaghan, C.M. (2012). Prosecuting presidents: The politics within Ecuador's corruption cases. Journal of Latin American Studies, 44(4), 649-678. https://doi.org/10.1017/S0022216X12000776

Constantin, S., Toulkeridis, T., Moldovan, O.T., Villacís, M., \& Addison, A. (2019). Caves and karst of Ecuador-state-of-the-art and research perspectives. Physical Geography, 40(1), 28-51. https://doi.org/10.1080/02723646.2018.1461496

DeYoung, D.B. (1994). Age of the Arizona Meteor Crater. Creation Research Society Quarterly, 31, 153-158. http://www.creation adventurefamily.com/files/CRS31-153.pdf

Diario Hoy 16-8-2000. Habrían encontrado vida extraterrestre. Diario Hoy. http://pdf.diariohoy.net/2000/08/16/pdf/19.pdf (Spanish)

Edwards, M.E. (2015). Understanding Presidential Failure in South America. Latin American Politics and Society, 57(2), 111-131. https://doi.org/10.1111/j.1548-2456.2015.00270.x

Ganapathy, R. (1980). A major meteorite impact on the earth 65 million years ago: Evidence from the Cretaceous-Tertiary boundary clay. Science, 209(4459), 921-923. https://doi.org/10.1126/science.209.4459.921

Ganapathy, R. (1982). Evidence for a major meteorite impact on the Earth 34 million years ago: Implication for Eocene extinctions. Science, 216(4548), 885-886. https://doi.org/10.1130/SPE190-p513

Gentile, G., \& Snell, H. (2009). Conolophus marthae sp. nov.(Squamata, Iguanidae), a new species of land iguana from the Galápagos archipelago. Zootaxa, 2201(1), 10. https://doi.org/10.11646/zootaxa.2201.1.1

Goodman, A.Y. (1996). Glacial Geology and Soil Catena Development on Moraines in Las Cajas National Park, Ecuador. Unpublished B.S. Thesis, Union College, Schenectady, NY.

Hager, D. (1953). Crater mound (Meteor Crater), Arizona, a geologic feature. AAPG Bulletin, 37(4), 821-857.

Hochstetler, K. (2006). Rethinking presidentialism: Challenges and presidential falls in South America. Comparative Politics, $401-418$. https://doi.org/10.2307/20434009

Hodych, J.P., \& Dunning, G.R. (1992). Did the Manicouagan impact trigger end-of-Triassic mass extinction?. Geology, 20(1), 51-54. https://doi.org/10.1130/0091-7613(1992)020<0051:DTMITE >2.3.CO;2

Hoese, G., Addison, A., Toulkeridis, T., \& Toomey III, R. (2015). Observation of the Catfish Chaetostoma microps Climbing in a Cave in Tena, Ecuador. Subterranean Biology, 15, 29. https://doi.org/10.3897/subtbiol.15.4809

Humphreys, C.J. (1991). The Star of Bethlehem - a Comet in BC 5 - and the Date of the Birth of Christ. Quarterly Journal of the Royal Astronomical Society, 32, 389.

Hungerbühler, D., Steinmann, M., Winkler, W., Seward, D., Egüez, A., Peterson, D.E., Helg, U., \& Hammer, C. (2002). Neogene stratigraphy and Andean geodynamics of southern Ecuador. Earth-Science Reviews, 57(1), 75-124. https://doi.org/10.1016/S0012-8252(01)00071-X

Kaiho, K., Kajiwara, Y., Nakano, T., Miura, Y., Kawahata, H., Tazaki, K., Ueshima, M., Chen, Z., \& Shi, G.R. (2001). End-Permian catastrophe by a bolide impact: evidence of a gigantic release of sulfur from the mantle. Geology, 29(9), 815-818. https://doi.org/10. 1130/0091-7613(2001)029<0815:EPCBAB>2.0.CO;2

Kennemore, A., \& Weeks, G. (2011). Twenty-first century socialism? The elusive search for a post-neoliberal development model in Bolivia and Ecuador. Bulletin of Latin American Research, 30(3), 267-281. https://doi.org/10.1111/j.1470-9856.2010.00496.x

Kolesnikov, E.M., \& Kolesnikova, N.V. (2010). Traces of cometary material in the area of the Tunguska impact (1908). Solar System Research, 44(2), 110-121. https://doi.org/10.1134/S0038094610020048

Korovkin, T. (2000). Weak weapons, strong weapons? Hidden resistance and political protest in rural Ecuador. The Journal of Peasant Studies, 27(3), 1-29. https://doi.org/10.1080/03066150008438738

Lowe, D.R. (2013). Crustal fracturing and chert dike formation triggered by large meteorite impacts, ca. $3.260 \mathrm{Ga}$, Barberton greenstone belt, South Africa. Geological Society of America Bulletin, 125(5-6), 894-912. https://doi.org/10.1130/B30782.1

Lucero, J.A. (2001). High anxiety in the Andes: crisis and contention in Ecuador. Journal of Democracy, 12(2), 59-73. https://doi.org/10.1353/jod.2001.0032

Lyall, A. (2018). A moral economy of oil: Corruption narratives and oil elites in Ecuador. Culture, Theory and Critique, 59(4), 380-399. https://doi.org/10.1080/14735784.2018.1507752

Llorca J.J.M., Trigo, J.L., Ortiz, J.A., Docobo, J., \& Garcia. (2005). The Villalbeto de la Peña meteorite fall: I. Fireball energy, meteorite recovery, strewn field and petrography. Meteoritics \& Planetary Science 40, 795-804. https://doi.org/10.1111/j.1945-5100.2005.tb00155.x

Marsteintredet, L., \& Uggla, F. (2019). Allies and traitors: Vice-presidents in Latin America. Journal of Latin American Studies, 51(3), 665688. https://doi.org/10.1017/S0022216X18001098

Martin, S., Toulkeridis, T., Addison, A., \& Pozo, W.E. (2016). Predation of Desmodus rotundus Geoffroy, 1810 (Phyllostomidae, Chiroptera) by Epicrates cenchria (Linnaeus, 1758) (Boidae, Reptilia) in an Ecuadorian Cave. Subterranean Biology, 19 , 41. https://doi.org/10.3897/subtbiol.19.8731

Mato, F., \& Toulkeridis, T. (2017). The missing Link in El Niño's phenomenon generation. Science of tsunami hazards, 36: 128-144. http://www.tsunamisociety.org/STHVol36N3Y2017.pdf

Moliner, M.B.C. (2011). Conservación in situ. Las plataformas cerámicas, del Parque Arqueológico de Cochasquí. Ecuador. In Patrimonium. Revista de Restauración y Museología 1(1), 1-10. (Spanish) http://hdl.handle.net/10251/29279

Moyano, C.E., \& Trigo, J.M. (2013). As acondritas: meteoritos de otros mundos Achondrites: meteorites from other worlds. Enseñanza de las Ciencias de la Tierra, 21(21.3), 273. 283930-Text de lárticle-391036-1-10-20141202.pdf

Napier, B., \& Asher, D. (2009). The Tunguska impact event and beyond. Astronomy \& Geophysics, 50(1), 1-18. https://doi.org/10. $1111 /$ j. 1468-4004.2009.50118.x

Naukas. (2013). Impacto de un asteroide en Rusia. Eureka. (Spanish). http://danielmarin.naukas.com/2013/02/15/impacto-de-un-asteroide-en-rusia/

Navarrete, E., Galindo, C.G., Prosperina, K., \& Perimetral, V. (2003). Huellas de un "frío pasado" patrimonio geológico del Parque Nacional El Cajas. El patrimonio geominero en el contexto de la ordenación territorial, 12, 181-197. (Spanish) https://www.researchgate.net/profile/Edison-Navarrete/publication/264895054_HUELLAS_DE_UN_FRIO_PASADO_PATRIMONIO_ GEOLOGICO_DEL_PARQUE_NACIONAL_EL_CAJAS/links/53f49ab10cf22be01c3ed377/HUELLAS-DE-UN-FRIO-PASADOPATRIMONIO-GEOLOGICO-DEL-PARQUE-NACIONAL-EL-CAJAS.pdf

Padrón, E., Hernández, P.A., Pérez, N.M., Toulkeridis, T., Melián, G., Barrancos, J., Virgili, G., Sumino H., \& Notsu, K. (2012). Fumarole/plume and diffuse CO2 emission from Sierra Negra volcano, Galapagos archipelago. Bull. Of Volcanol., 74, $1509-1519$. https://doi.org/10.1007/s00445-012-0610-4 
Perreault, T., \& Valdivia, G. (2010). Hydrocarbons, popular protest and national imaginaries: Ecuador and Bolivia in comparative context. Geoforum, 41(5), 689-699. https://doi.org/10.1016/j.geoforum.2010.04.004

Popova, O.P., Jenniskens, P., Emel'yanenko, V., Kartashova, A., Biryukov, E., Khaibrakhmanov, S., Shuvalov, V., Rybnov, Y., Dudorov, A., Grokhovsky, V.I., Badyukov, D.D., Yin, Q.Z., Gural, P.S., Albers, J., Granvik, M., Evers, L.G., Kuiper J., Kharlamov, V., Solovyov, A., Rusakov, Y.S., Korotkiy, S., Serdyuk, I., Korochantsev, A.V., Larionov, M.Y., Glazachev, D., Mayer, A.E., Gisler, G., Gladkovsky, S. V., Wimpenny, J., Sanborn, M.E., Yamakawa, A., Verosub, K., Rowland, D.J., Roeske, S., Botto, N.W., Friedrich, J.M., Zolensky, M., Le, L., Ross, D., Ziegler, K., Nakamura, T., Ahn, I., Lee, J.I., Zhou, Q., Li, X.H., Li, Q.L., Liu, Y., Tang, G.Q., Hiroi, T., Sears, D., Weinstein, I.A., Vokhmintsev, A.S., Ishchenko, A.V., Schmitt-Kopplin, P., Hertkorn, N., Nagao, K., Haba, M.K., Komatsu, M., \& Mikouchi, T. (2013). Chelyabinsk airburst, damage assessment, meteorite recovery, and characterization. Science, 342(6162), 10691073. https://doi.org/10.1126/science. 1242642

Pratt, W.T., Duque, P., \& Ponce, M. (2005). An autochthonous geological model for the eastern Andes of Ecuador. Tectonophysics, 399(1), 251-278. https://doi.org/10.1016/j.tecto.2004.12.025

Ridgely, R.S., \& Greenfield, P.J. (2001). The birds of Ecuador. Field guide, Cornell, 1, 740.

Rietmeijer, F.J. (2000). Interrelationships among meteoric metals, meteors, interplanetary dust, micrometeorites, and meteorites. Meteoritics \& Planetary Science, 35(5), 1025-1041. https://doi.org/10.1111/j.1945-5100.2000.tb01490.x

Rodriguez, F., Toulkeridis, T., Padilla, O., \& Mato, F. (2017). Economic risk assessment of Cotopaxi volcano Ecuador in case of a future lahar emplacement. Natural Hazards, 85, (1), 605-618. https://doi.org/10.1007/s11069-016-2589-1

Rumazo, J. (1946). La región amazónica del Ecuador en el siglo XVI. Anuario de Estudios Americanos, 3, 1-268. (Spanish)

Schulte, P., Alegret, L., Arenillas, I., Arz, J.A., Barton, P.J., Bown, P.R., Bralower, T.J., Christeson, G.L., Claeys, P., Cockell, C.S., Collins, G.S., Deutsch, A., Goldin, T.J., Goto, K., Grajales, J.M., Grieve, R.A.F., Gulick, S.P.S., Johnson, K.R., Kiessling, W., Koeberl, C., Kring, D.A., MacLeod, K.G., Matsui, T., Melosh, J., Montanari, A., Morgan, J.V., Neal, C.R., Nichols, D.J., Norris, R.D., Pierazzo, E., Ravizza, G., Rebolledo, M., Reimold, W.U., Robin, E., Salge, T., Speijer, R.P., Sweet, A.R., Urrutia, J., Vajda, V., Whalen, M.T., Willumsen, P.S. (2010). The Chicxulub asteroid impact and mass extinction at the Cretaceous-Paleogene boundary. Science, 327(5970), 1214-1218. https://doi.org/10.1126/science. 1177265

Smit, J. (1990). Meteorite impact, extinctions and the Cretaceous-Tertiary boundary. Geologie en Mijnbouw,69(2), 187-204. https://www.researchgate.net/profile/Jan-Smit-6/publication/27710988_Meteorite_impact_extinctions_and_the_Cretaceous-

Tertiary_Boundary/links/56e9e87108aec8bc078148e4/Meteorite-impact-extinctions-and-the-Cretaceous-Tertiary-Boundary.pdf

Snow, B.K. (1979). The Oilbirds of Los Tayos. The Wilson Bulletin, 91(3), 457-461.

Soto, G.J. (2004). Meteoritos y meteoros en Costa Rica (verdaderos, posibles y falsos). Revista Geológica de América Central, $31,7-23$. (Spanish) https://doi.org/10.15517/RGAC,V0I31.7241

Suhr, N., Rojas-Agramonte, Y., Chew, D.M., Pinto, A.J., Villagómez-Díaz, D., Toulkeridis, T., \& Mertz-Kraus, R. (2019). Detrital-zircon geochronology and provenance of the El Oro Metamorphic Complex, Ecuador: Geodynamic implications for the evolution of the western Gondwana margin. Journal of South American Earth Sciences, 90, 520-539. https://doi.org/10.1016/j.jsames.2018.12.010

Svetsov, V.V., Nemtchinov, I.V., \& Teterev, A.V. (1995). Disintegration of large meteoroids in Earth's atmosphere: Theoretical models. Icarus, 116(1), 131-153. https://doi.org/10.1006/icar.1995.1116

Svistoonoff, N. (1994). Mystery and seduction: Orchids of Ecuador. Andes Editores; 1st edition, Quito, Ecuador, $161 \mathrm{pp}$.

Tobar, L., \& Solano, S. (2019). The perception of poor people from the canton of Cuenca-Ecuador on corruption (2010-2017 period). Journal of Legal, Ethical and Regulatory Issues, 22(3), 1-15. https://search.proquest.com/openview/8468a43d26a9dc9338df $2214 \mathrm{e} 04 \mathrm{~b} 6622 / 1$ ?pq-origsite $=$ gscholar $\& \mathrm{cbl}=38868$

Toulkeridis, T., \& Zach, I. (2017). Wind directions of volcanic ash-charged clouds in Ecuador - Implications for the public and flight safety. Geomatics, Natural Hazards and Risks, 8(2), 242-256. https://doi.org/10.1080/19475705.2016.1199445

Toulkeridis, T., Porras, L., Tierra, A., Toulkeridis, K., Cisneros, D., Luna, M., Carrión, J.L., Herrera, M., Murillo, A., Perez, J.C., Tapia, S., Fuertes, W., \& Salazar, R. (2019). Two independent real-time precursors of the $7.8 \mathrm{Mw}$ earthquake in Ecuador based on radioactive and geodetic processes Powerful tools for an early warning system. Journal of Geodynamics, 126, 12-22. https://doi.org/10.1016/j.jog.2019.03.003

Toulkeridis, T., Tamayo, E., Simón, D., Merizalde, M.J., Reyes, D.F., Viera, M., \& Heredia, M. (2020). Climate change according to Ecuadorian academics-Perceptions versus facts. La Granja, 31(1), 21-49. https://doi.org/10.17163/lgr.n31.2020.02

Toulkeridis, T., Rodríguez, F., Arias, N., Simón, D., Salazar R., Addison, A., Freyre, D., Mato, F., \& Díaz, C. (2016). Causes and consequences of the sinkhole at El Trébol of Quito, Ecuador - Implications for economic damage and risk assessment. Natural Hazards and Earth Science System, 16, 2031-2041. https://doi.org/10.5194/nhess-16-2031-2016

White, R.V., \& Saunders, A.D. (2005). Volcanism, impact and mass extinctions: incredible or credible coincidences? Lithos, 79(3), 299-316. https://doi.org/10.1016/j.lithos.2004.09.016

Ziólkowski, M.S., \& Sadowski, R.M. (1991). Investigaciones arqueoastronómicas en el sitio de Ingapirca, Prov. de Cañar, Ecuador. Archeologia e Astronomia. 151-162, (Spanish). https://ui.adsabs.harvard.edu/abs/1991aras.conf..151Z

Article history: Received: 06.01.2021 Revised: 16.02.2021 Accepted: 29.03.2021 Available online: 19.04.2021

